\title{
A STRUCTURAL MODEL PROPOSAL FOR ATTITUDES OF TURKISH CONSUMERS' TOWARDS DISCOUNT STORES' PRIVATE LABELS
}

\author{
TÜRK TÜKETİCILERIN İNDİRIM MAĞAZALARININ ÖZEL \\ MARKALARINA YÖNELİK TUTUMLARINA İLIŞKİN BİR YAPISAL \\ MODEL ÖNERISİ
}

Tamer BARAN ${ }^{* *}$ iD

\begin{abstract}
The purpose of this study is to construct a structural model of consumers' attitudes towards private labels of discount stores and testing this model. Accordingly, three stores, which have operated in discount retailing and largest store number in Turkey, were included in the study. Based on the Turkish Statistical Institute Provincial Life Index report, the data were obtained from 14 provinces and 14 districts of these provinces, randomly determined from the provinces where all three stores were located in the city center and at least one district. The data obtained from 1230 respondents with a face-to-face survey and tested with the Structural Equation Modeling (SEM) method using the AMOS statistical program. In the result of the study, it was found that store atmosphere is the most influential variable to consumers' perceived quality. On the other hand, findings showed that price has the highest effect on attitude towards private labeled products of the discount stores. Moreover, the model fit indexes result show that the use of the theoretical model of the study is suitable for discount stores.
\end{abstract}

Keywords: Private Label, Perceived Quality, Perceived Risk, Price, Store Atmosphere.

JEL Classification: M30, M31, M39.

Öz

Bu çalışmanın amacı, tüketicilerin indirim mağazalarının özel markalarına yönelik tutumlarına ilişkin bir yapısal model oluşturmak ve bu modeli test etmektir. Bu doğrultuda Türkiye'de indirim mağazası olarak faaliyet gösteren ve en çok mağazaya sahip 3 mağaza çalışmanın kapsamına alınmıştır. Veriler Türkiye

* This article was derivatived from the author's doctoral dissertation and supported by coordinatorship of scientific research projects of Pamukkale University with the project numbered 2017 SOBE013.

** PhD Lecturer, Pamukkale University, Kale VS, Travel-Tourism and Entertainment Department, tbaran@pau.edu.tr, ORCID: 0000-0002-8711-6561.

To cite this article: Baran, T. (2021). A structural model proposal for attitudes of Turkish consumers' towards discount stores' private labels.Journal of Research in Business, 6(2), 274-289.

"There is no requirement of Ethics Committee Approval for this study." 
İstatistik Kurumunun illere göre yaşam indeksi temel alınarak her üç mağazanın şubesinin de bulunduğu ve tesadüfi olarak belirlenmiş 14 il ve bu illere bağlı 14 ilçede yerleşik tüketicilerden elde edilmiştir. Yüz yüze anket aracılı̆̆ıyla toplanan veriler, AMOS istatistik programından faydalanılarak Yapısal Eşitlik Modellemesi (YEM) ile analiz edilmiştir. Çalışma sonucunda tüketicilerin indirim mağazalarının ürünlerine karşı algıladıkları kaliteyi en fazla mağaza atmosferinin etkilediği bulunmuştur. Bununla birlikte çalışmanın bulgularına göre, tüketicilerin indirim mağazalarının özel markalı ürünlerine yönelik tutumu en fazla fiyat etkilemektedir. YEM sonucunda ortaya çıkan model uyum indeksleri, çalışmanın teorik modelinin kullanımının indirim mağazaları için uygun olduğunu göstermektedir.

Anahtar Kelimeler: Özel Marka, Algılanan Kalite, Algılanan Risk, Fiyat, Mağaza Atmosferi.

JEL Sinıflamasi: M30, M31, M39.

\section{Introduction}

Private labels are names owned by a retailer or wholesaler and used only by a particular retailer or wholesaler (Berman et al., 2018). They emerged in the second half of the 19th century and have been in the market over time as an alternative for national and international brands for consumers (Martos Partal et al., 2015). Hence, the market shares of private labeled products have increased significantly in the USA and Europe (plminternational, 2016). This increasing demand for private label products also captivates researchers, and studies on the subject have been carried out in different countries recently. However, in these studies, developing economies were not touched on sufficiently and were focused on North America and Europe (Riboldazzi et al., 2021). Moreover, there are very few studies investigating the attitudes of Turkish consumers towards private label products.

In this context, this study aims to propose and test a structural model on consumers' attitudes towards private labels of discount stores in Turkey as a developing economy. At the end of the study, the following questions will be answered:

$\mathrm{RQ}_{1}$ : Which features of discount stores affect consumers' quality perception towards private label products?

$\mathrm{RQ}_{2}$ : Which features of discount stores affect consumers' risk perception towards private label products?

$\mathrm{RQ}_{3}$ : Do consumers' perceptions affect the attitudes towards discount stores' private labeled products?

The study is organized as follows. In the next section, the concepts used in the study are explained, and a conceptual model is created with the variables of the working model. Afterward, the methodology section explains the scope of the study, its sample, measurement tools and analysis method. Then, the findings attained as a result of the analysis are presented, and the study concludes with the discussion and conclusion sections. 


\section{Literature Review and Hypothesis Development}

\subsection{Store Atmosphere - Perceived Quality}

The store atmosphere is the effort to design the store environment to create effects that will help increase the customer's probability of purchasing (Poncin and Mimoun, 2014). The store atmosphere is more important for retailers than producers and wholesalers. Kotler (1973) claimed that the store atmosphere is as important as the basic products and that there is a "silent language" to the retailer's communication with the consumers. Kotler (1973) stated that retailers could build their store atmosphere on sensory elements such as visual, auditory, olfactory and tactile. On the other hand, some authors (Miranda et al., 2005; Sirohi et al., 1998) considered the store atmosphere through physical factors, such as the in-store placement of the products, the ease of access to the shelves, etc. Atmosphere is crucial to retailers because the store atmosphere is one factor that affects the consumers' quality perception of the store's products.

In previous studies, researchers revealed the effect of store atmosphere on consumers' perceived quality. Babin et al. (2004) found that atmosphere positively affected USA consumers' perceived quality. Baker et al., (2002) found that store atmosphere strongly affects university students' quality perception in the USA. Similarly, Dursun et al. (2011) showed that store atmosphere affects the consumers' quality perception of the store's products. Vahie and Paswan (2006) revealed similar

findings, stating that atmosphere influences the consumers' perceived quality of the store's products. In line with these findings, the first hypothesis of the study follows:

$\mathbf{H}_{1}$ : Store atmosphere affects the consumers' perceived quality to discount stores' products.

\subsection{Pricing Strategy - Perceived Quality}

In the literature, price is addressed in two approaches, in terms of consumers and firms. For the consumers, price is the cost incurred to obtain a benefit (Lichtenstein et al, 1993), while for the firms, it is the value attributed to the product (Ahtola, 1984). In the context of the retailing industry, two strategies have been generally used in pricing, namely promotional pricing and EDLP (Fassnacht and Husseini, 2013; Kopalle vd, 2009; Trios and Hardesy, 2010). While promotional pricing is a strategy generally used by hypermarkets, EDLP is the pricing strategy preferred by discount stores (Baran, 2019; Bardakc1 and Baran, 2019).

Discount stores reflect their low operational costs to consumers by offering their products at low prices. In addition to the advantages of operating with low prices, there are some handicaps. Perhaps the most important of these handicaps is that low price causes consumers to perceive that discount stores' products are low quality because price is one of the most important determinations of the perceived quality (Zeithaml, 1988). Consumers generally evaluate a product's quality by considering the price of the product (AMA, 2021), consumers perceive a product as higher quality as the price increases and lower quality as the price decreases (Aaker, 1991). 
Some researchers exhibited the effect of price on consumers' quality perception. Agarwal and Teas (2001) stated that price positively affected consumers' quality perception. The study showed that consumers think that the higher the price of a product, the higher quality of this product. Baran (2021b) exhibited that the pricing strategy of discount stores has a strong positive effect on consumers' perceived quality in Turkey. On the other hand, as the price decreases, so, too, does the product's perceived quality. Beneke et al. (2013) and Beneke et al. (2015) mentioned that price positively affects the perceived quality of private label products. Dawar and Parker (1994) found that price is one of the most important indicators of perceived quality in their studies. In the direction of these findings, the second hypothesis of this study is as below:

$\mathbf{H}_{2}$ : Price affects consumers' quality perception.

\subsection{Pricing Strategy - Attitudes towards Private Labels}

In addition to being one of the most important indicators of quality, price is also a factor that affects consumers' attitudes towards private labeled products. Price is one of the most important tools that firms use to pass on the message to consumers that their products or brands have different characteristics than the competitors in the market (Ahtola, 1984).

The findings of studies have revealed the effect of price on consumers' attitudes towards private labeled products. Burton et al. (1998) stated that the price of private labeled products is one of the determinants of the attitude towards these products. The study of Ahmad et al. (2014), which covers Tesco's private labeled products in Malaysia, showed that as the price increases, the attitude of consumers towards private label products also changes positively. Similarly, in their study on breakfast cereal in South Africa, Beneke and Zimmerman (2014) found that the price positively affected consumers' attitudes to private label products. Erdil's study (2015) indicated that the price positively affected consumers' attitudes to private label products in Turkey. As a result of his study on Thai consumers, Thanasuta (2015) revealed that the prices of private label products positively affect the attitude towards these products. Zielke and Komor (2015) conducted their study in discount stores and hypermarkets in Germany and Poland that deal with food, electronics, clothing and cosmetic products. The findings exhibited that the price positively affects consumers' attitudes to private label products. With reference to findings of previous studies, the third hypothesis of the present study was stated as follows:

$\mathbf{H}_{3}$ : Price affects consumers' attitudes to private labels.

\subsection{Pricing Strategy - Perceived Risk}

Pricing strategy has also affected the consumers' risk perceptions, especially for discount stores (Baran, 2021a). Bettman's (1973) study, which included 123 housewives in the USA and covered products in nine different categories, showed that the price has a negative effect on the perceived risk. 
According to the findings, as the price of the products in the categories increases, the level of risk perceived by housewives against the product decreases, and as the price of the products decreases, the level of risk perceived by housewives increases. Grewal, Gotlieb and Marmorstein's (1994) study, involving 131 students in the USA, tested the effect of price on the perceived risk in a video recorder. As a result, the authors found that similar to the findings of Bettman (1973), as the price increases, the perceived risk by the students decreases, and as the price decreases, the perceived risk increases. Narasimhan and Wilcox (1998) found that private label products are perceived as risky by consumers, although the level of risk varies from person to person. Gonzalez-Benito and MartosPartal (2012) investigated the food, personal care and household goods belonging to 10 stores which operate in Spain in their study. The study's findings revealed that the price has a negative effect on the consumers' risk perceptions. Starting from these findings, the fourth hypothesis of the study is expressed as follows:

$\mathbf{H}_{4}$ : Price affects consumers' risk perception.

\subsection{Perceived Quality - Perceived Risk}

Perceived quality is the sum of consumers' judgments about the overall excellence or superiority of the product or brand (Aaker, 1991; Ophius \& Van Trijp, 1995). Zeithaml (1988) defines perceived quality as the set of feelings and thoughts developed by consumers about the product or brand during the purchasing process. Perceived quality is different from actual quality. Actual quality refers to measurable and verifiable excellence on some predetermined ideal standard or standard of product or brand. However, perceived quality is the sum of judgments formed in the minds of consumers about the product or the brand (Zeithaml, 1988).

The consumers' quality perceptions are one of the important determinants of their risk perceptions towards products or brands. Consumers perceive high-quality products or brands as less risky, and products or brands with relatively low quality perception as more risky (Snoj et al., 2004). Studies conducted reveal findings that support this claim.

Baran (2021b) revealed that perceived quality is an important antecedent of the perceived risk for discount store customers. The author showed that as the consumers' quality perception towards discount stores' products increases, the risk perceptions significantly decreases. Beneke (2012) established that perceived product quality negatively affects the consumer's risk perception. Beneke et al. (2015) exhibited that the perceived quality of middle-income consumers in South Africa strongly negatively affects their perceived risk to products. Kim and Lennon (2013) verified that the consumers' perceived quality against the online store negatively affects their perceived risk towards this store in the USA. Snoj et al. (2004) found that the quality perceived by university students against mobile phones in Slovenia has strongly negative affected their perceived risk. Hence, the fifth hypothesis of the current study is presented as follows:

$\mathbf{H}_{5}:$ Consumers' perceived quality affects perceived risk. 


\subsection{Perceived Quality - Attitude towards Private Labels}

As mentioned before, perceived quality is the sum of judgments formed in the minds of consumers about the product or brand. These judgments affect the consumers' perceived risk towards a product or brand as well as attitude towards such a product or brand (Baran, 2020). Many previous studies have provided findings demonstrating this effect.

In their study, which includes five major retail stores in Spain, Calvo-Porral and Lang (2015) exposed that the quality perceived by consumers towards private label products positively affected the attitude towards these products. Cappliure et al. (2015) revealed that the perceived quality of private label products positively affected the attitude towards these products. Konuk (2018) examined the effect of the Turkish consumers' quality perception towards organic products on their attitudes and revealed that the perceived quality affects the attitude positively. In their study on coffee and detergent products in Germany, Olbrich et al. (2017) executed that the perceived quality of private label food and non-food products positively affect attitudes towards these products. Moreover, the effect of perceived quality on attitude in private labeled products is more than the effect of quality on attitude in nationally branded products. In this respect, the sixth hypothesis of the actual study is created as:

$\mathbf{H}_{6}$ : Consumers' quality perception towards products of discount stores affects their attitudes towards private labels of discount stores.

\subsection{Perceived Risk - Attitude towards Private Labels}

The definitions of perceived risk, first used by Bauer (1960) in the field of marketing, focus on the uncertainty (Cox and Rich, 1964; Truong vd., 2017) and loss (Marriott and Williams, 2018; Stone and Grønhaug, 1993). In the context of uncertainty, perceived risk expresses the negative consequences consumers will encounter after purchasing (Truong et al., 2017), while the context of loss is stated as the sum of the losses that the consumer thinks can be incurred as a consequence of purchasing a product or brand (Marriott and Williams, 2018). Whether in the context of uncertainty or loss, the consumers' perceived risk is one of the factors that affect their attitudes towards a product or brand.

In previous studies, Baran (2021b) revealed that Turkish consumers' risk perceptions have a strong negative effect on attitudes towards private labeled products. Batra and Sinha (2000) found that as consumers' risk perceptions increase, their attitudes towards private label products change negatively. In the study carried out by Erdil (2015) in Turkey, it was found that the risk perceived by consumers towards private labeled products negatively affected their attitudes towards these products. In their study conducted in Spain, Gomez and Rubio (2010) examined seven stores, which exposed that the consumers' perceived risk strongly affects their negative attitudes towards private label products. Semeijn et al. (2004) dealt with four different product groups belonging to three retail stores operating in Dutch. They revealed that the risk perceived by consumers towards private label products negatively affected their attitudes towards these products. Similarly, Sheau-Fen et al. (2012), in their study, which investigated three large retail stores operating in Malaysia, disclosed 
that the risk perceived by consumers towards private label products negatively affected their attitudes towards private label products. The findings of Wu et al. (2011) also indicated that the consumers' risk perception strongly affects their attitudes towards private label products in a negative way in Taiwan. In light of these findings, the last hypothesis of the study is as follows:

$\mathbf{H}_{7}$ : Perceived risk affects consumers' attitudes towards private labels of discount stores.

The structural model of the research, which was created in the light of the literature review and hypotheses of the study, is presented in Figure 1.

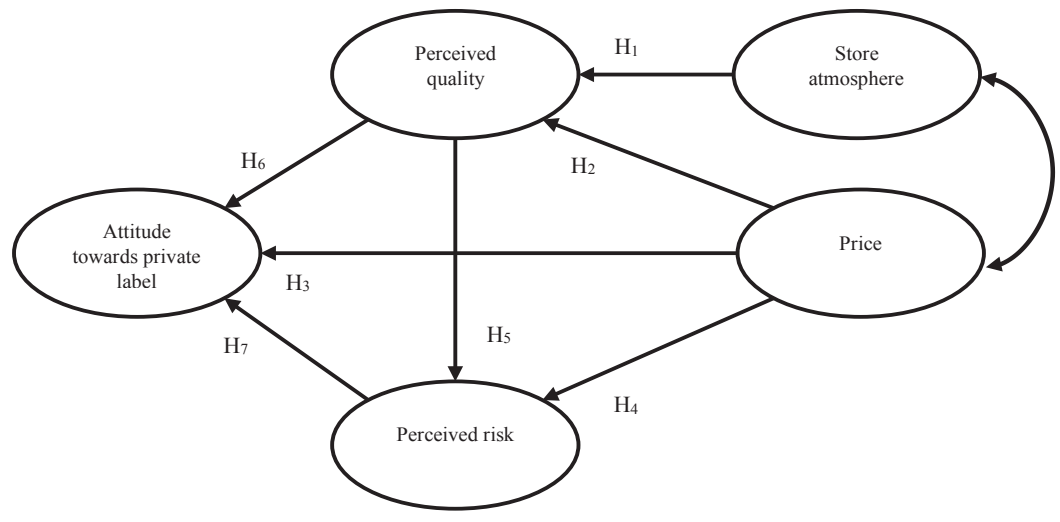

Figure 1: Theoretical model of the study

\section{Methodology}

This study focuses on consumers' attitudes towards private labels of discount stores in Turkey as a rapidly emerging market. The study involves three discount stores with more than 25,000 store counts and are the most preferred (nearly $85 \%$ ) discount stores by consumers in Turkey. The data were gathered by a questionnaire from 1230 participants residing in 14 provinces and districts that were determined randomly. The questionnaire was structured in two main parts. In the first part, scales of the variables of the study were included. In this part, the store atmosphere scale, developed by Koo (2003) and consisting of 4 items, was used (sample item; Products are well displayed at X). Consumers' evaluations towards prices of discount stores were obtained by using Zielke's (2006) price scale, consisting of 3 items (sample item, In the X, products are sold at low prices). Grewal et al.'s (1998) perceived quality scale was used to get the consumers' quality perception towards discount stores' products (sample item, Products of $X$ are durable in appearance). The perceived risk scale, developed by Laroche et al. (2005) was used to gather consumers' risk perceptions towards discount stores' products (sample item, Shopping at $X$ is very risky). Finally, to measure consumers' attitudes towards private labels, the scale developed by Burton et al. (1998) was used (sample item, I feel good when I buy X's own branded products). All the scales were presented to participants as a 5-point Likert type scale in the questionnaire, as it was easy to understand by the participants (Baran, 2020). 
The second part of the questionnaire involved from the demographics of participants (for example, gender, household, age, occupation etc.). In the study, in addition to descriptive, the Structural Equation Model was used to analyze data through the AMOS statistical program. The results are presented in the next section in detail.

\section{Findings}

The gender distribution of the participants is equal (male 51,6\% $\mathrm{n}=635$; female 48,4\%, $\mathrm{n}=595$ ). According to the number of people living in the household, the lowest rate is the group of participants with 2 or less households $(\% 20,7)$, the participants with 4 or more households has the highest $(29,3)$ rate. In terms of age range, participants between the ages of $18-25$ have the highest rate $(n=538$, $43,74 \%)$, while the group of participants aged 56 and over has the lowest rate $(n=108,8,78 \%)$. Over $30 \%$ data were obtained from all stores included in the scope of the study (BIM, 33.9\%, $\mathrm{n}=417$; A101, 32.4\%, $\mathrm{n}=399$; Şok, 33.7\%, $\mathrm{n}=414$ ). This is important due to the close representation of discount stores to each other in the study.

Before proceeding to the SEM analysis, Confirmatory Factor Analysis (CFA) of the measurement model was performed. Analysis results are presented in Table 1 in detail.

Table 1: CFA and Reliability Analysis of the Construct

\begin{tabular}{|c|c|c|c|c|c|}
\hline Variable & Item & Factor Loadings & Cronbach's $\alpha$ & AVE & $\mathrm{CR}$ \\
\hline \multirow{6}{*}{ Attitude } & ATT1 & 0,83 & \multirow{6}{*}{, 783} & \multirow{6}{*}{,422 } & \multirow{6}{*}{, 796} \\
\hline & ATT2 & 0,82 & & & \\
\hline & ATT3 & 0,69 & & & \\
\hline & ATT4 & 0,21 & & & \\
\hline & ATT5 & 0,49 & & & \\
\hline & ATT6 & 0,64 & & & \\
\hline \multirow{3}{*}{ Price } & $\mathrm{P} 1$ & 0,66 & \multirow{3}{*}{,714 } & \multirow{3}{*}{,454 } & \multirow{3}{*}{, 713} \\
\hline & $\mathrm{P} 2$ & 0,70 & & & \\
\hline & P3 & 0,66 & & & \\
\hline \multirow{4}{*}{ Atmosphere } & ATM1 & 0,66 & \multirow{4}{*}{,778 } & \multirow{4}{*}{,476 } & \multirow{4}{*}{, 783} \\
\hline & ATM2 & 0,77 & & & \\
\hline & ATM3 & 0,71 & & & \\
\hline & ATM4 & 0,61 & & & \\
\hline \multirow{4}{*}{ Perceived Risk } & PR1 & 0,65 & \multirow{4}{*}{812} & \multirow{4}{*}{, 529} & \multirow{4}{*}{, 817} \\
\hline & PR2 & 0,76 & & & \\
\hline & PR3 & 0,79 & & & \\
\hline & PR4 & 0,70 & & & \\
\hline \multirow{3}{*}{ Perceived Quality } & PQ1 & 0,60 & \multirow{3}{*}{,759 } & \multirow{3}{*}{, 531} & \multirow{3}{*}{, 768} \\
\hline & PQ2 & 0,87 & & & \\
\hline & PQ3 & 0,69 & & & \\
\hline
\end{tabular}


Cronbach's a coefficients of all scales used in the study are above ,70 (store atmosphere ,778; price ,714; perceived quality ,759; perceived risk ,812; attitude towards private label ,783). Kline (2011), Nakip (2013) and Nunnally (1978) stated that the a coefficient should be above .70 for the scale to be considered reliable. In this context, it is seen that all scales used in the study are sufficiently reliable.

The values of the squared correlations of the scales' items, other than the fourth item of the private brand scale, were calculated between .25 and .57 . The squared correlation value of the item in question remained below .04. Moreover, the items of the scales used in the study were analyzed with CFA, and the fourth item of private label scale (In general, private labeled products of $X$ are low quality), which was found to be problematic among the items of all scales, was removed from the scale. After the removal of this item, Attitude Towards Private Label Scale's AVE value of the increased to .497 and Construct Reliability (CR) value rose to .827. Average Variance Extracted (AVE) values for the scales vary between .45 and .54 , while all CR values are above .70 .

According to the results of the fit indices of CFA regarding the construct validity of the model used in the study $\left(\chi^{2}: 796,435 ; d f: 160 ; \chi^{2} / d f: 4,978\right.$; p: <,001; CFI: ,856; RMSEA: ,060; GFI: ,929; AGFI: ,906; SRMR: ,0655), it can be said that the construct validity of the study is at an acceptable level (Hooper et al., 2008; Steiger, 2007; Sümer, 2000).

The correlations among the variables are presented in Table 2. Among the variables, it is found that perceived risk has a low and significant relationship with price and atmosphere, while there is no significant relationship with private brand attitude and perceived quality. On the other hand, it is seen that variables other than perceived risk have statistically significant relationships with each other.

Table 2: Correlation Coefficients among Variables

\begin{tabular}{|c|c|c|c|c|c|c|}
\hline & & $\overline{\mathbf{x}}_{\mathrm{pL}}$ & $\overline{\mathbf{x}}_{\mathrm{p}}$ & $\overline{\mathbf{x}}_{\text {ATM }}$ & $\overline{\mathbf{x}}_{\mathrm{PR}}$ & $\overline{\mathbf{x}}_{\mathrm{pQ}}$ \\
\hline$\overline{\mathbf{x}}_{\mathrm{P}}$ & $r$ &, $569^{* * \star}$ & 1 & & & \\
\hline$\overline{\mathbf{x}}_{\mathrm{ATM}}$ & $r$ &, $507^{* * *}$ &, $476^{* * *}$ & 1 & & \\
\hline$\overline{\mathbf{x}}_{\mathrm{PR}}$ & $r$ &,- 014 &,$- 095^{* *}$ &,$- 069^{*}$ & 1 & \\
\hline$\overline{\mathbf{x}}_{\mathrm{PQ}}$ & $r$ &, $464^{* * *}$ &, $389^{* * *}$ &, $438^{* * *}$ &,- 019 & 1 \\
\hline & & 3,29 & 3,50 & 3,46 & 2,74 & 3,38 \\
\hline & & 6964 &, 7287 & ,7436 & 8861 & ,7637 \\
\hline
\end{tabular}

${ }^{* * *} \mathrm{p}<, 001,{ }^{* *} \mathrm{p}<, 01,{ }^{\star} \mathrm{p}<, 05$

The effects among the variables in the theoretical model of the research are shown in Table 3. As can be seen from the table, the highest direct and total effects among the independent variables is the effect of price on attitudes towards private brands $(\beta=, 613 ; \beta=, 695$, respectively). Among the variables in the model, the highest indirect effect is the effect of the store atmosphere on the attitude towards the private brand $(\beta=, 101)$. On the other hand, among the mediating variables the highest direct and total effect is the effect of perceived quality on attitudes towards private brands $(\beta=, 268)$. 
Table 3: Direct, Indirect and Total Effects among Variables of the Theoretical Model

\begin{tabular}{cccccc}
\hline \multirow{4}{*}{ Perceived quality } & & Store atmosphere & Price & Perceived quality & Perceived risk \\
& Direct effect &, 375 &, 274 & - & - \\
& Indirect effect & - & - & - & - \\
& Total effect &, 375 &, 274 & - & - \\
\cline { 3 - 6 } Perceived risk & Direct effect & - &,- 154 &, 048 & - \\
& Indirect effect &, 018 &, 013 & - & - \\
& Total effect &, 018 &,- 141 &, 048 & - \\
\cline { 3 - 6 } Private label & Direct effect & - &, 613 &, 271 &,- 056 \\
attitude & Indirect effect &, 101 &, 082 &,- 003 & - \\
& Total effect &, 101 &, 695 &, 268 &,- 056 \\
\hline
\end{tabular}

The results of the study hypotheses are exhibited in Figure 2, which includes the theoretical model. Accordingly, our findings support all hypotheses except the fifth hypothesis of the study. Moreover, among the hypotheses supported in the study, only the seventh hypothesis, which states that the perceived risk affects the attitude towards the private brand, is at the ,05 significance level, while the significance level of all the other hypotheses supported is, 001 .

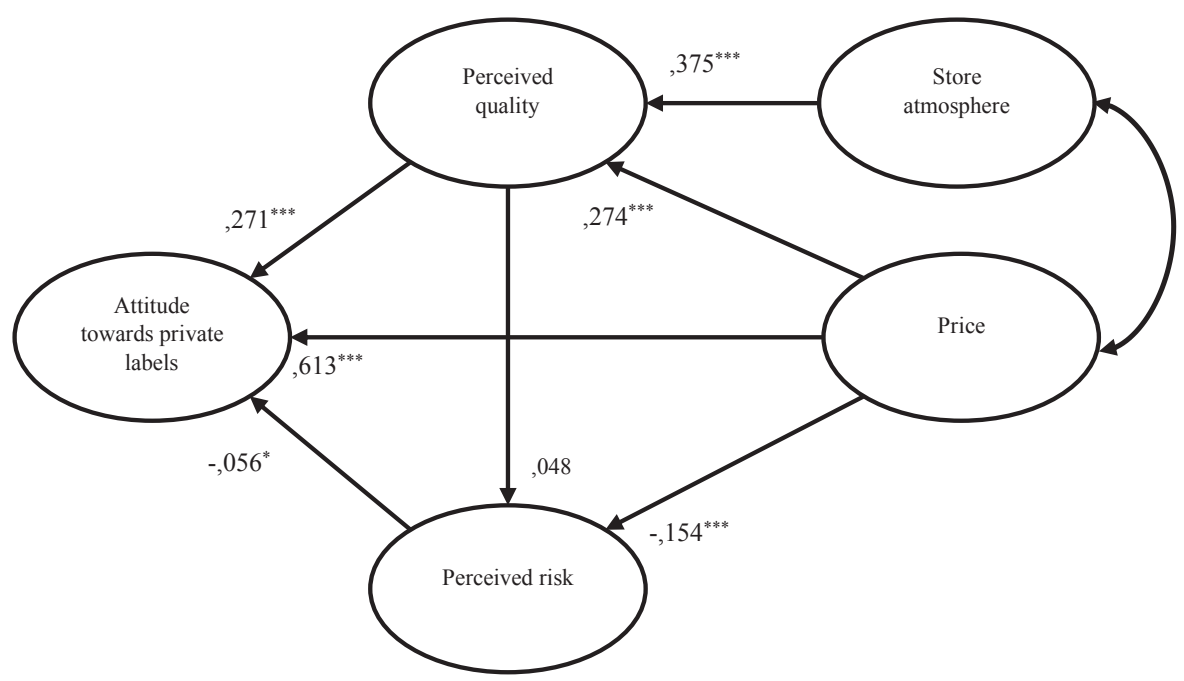

${ }^{* * *} \mathrm{p}<, 001,{ }^{*} \mathrm{p}<, 05$

Figure 2: Theoretical model results

Fit indices results of the study model are shown in Table 4 . Although the $X^{2} / d f$ value is slightly above the allowable level, it can be interpreted as moderately congruent. All other fit measurements are within the acceptable range. This shows that the theoretical model created is convenient. 
Table 4: Fit indices of the theoretical model of the study

\begin{tabular}{|c|c|c|c|c|}
\hline Indixes & $\begin{array}{l}\text { Current } \\
\text { Values }\end{array}$ & $\begin{array}{c}\text { Acceptable } \\
\text { level }\end{array}$ & Result & Reference(s) \\
\hline$d f$ & 160 & & & \\
\hline$X^{2}$ & 812,863 & & & \\
\hline$p$ & $<, 001$ & & & \\
\hline$X^{2} / d f$ & 5,08 & $<, 05$ & Reasonable fit & Sümer (2000) \\
\hline NFI & ,908 & $\geq 0.90$ & Acceptable fit & Schumaker and Lomax, 1996; Tabachnik and Fidell, 2001. \\
\hline TLI & 910 & $\geq 0.90$ & Acceptable fit & Bagozzi and Yi, 2012; Tabachnik and Fidell, 2001. \\
\hline CFI & ,925 & $\geq 0.90$ & Acceptable fit & $\begin{array}{l}\text { Cheung and Rensvold, 2002; Kunnan, 1998; Schermelleh - } \\
\text { Engel et al., 2003; Sümer, 2000; Tabachnik and Fidell, } 2001 .\end{array}$ \\
\hline RMSEA & 058 & $<, 06$ & Acceptable fit & Schreiber et al., 2006. \\
\hline SRMR & 041 & $<, 05$ & Acceptable fit & Schermelleh-Engel et al., 2003. \\
\hline
\end{tabular}

\section{Discussion and Conclusion}

In this study, consumers' attitudes towards private labeled products were investigated in Turkey. Data were collected from randomly determined 14 provinces and a district of these provinces. In the study, a questionnaire created by making use of the literature and a face-to-face approach was used. The data obtained were analyzed with the Structural Equation Modeling in the AMOS software. The findings of the study make important contributions to the literature in terms of both theoretical and managerial aspects.

The findings of some studies (Babin et al., 2004; Baker et al., 2002; Vahie and Paswan, 2006), conducted mostly in the USA as a developed economy, revealed that the store atmosphere affects the quality perceptions of the consumers. This study supported the findings of previous studies by proving that the atmosphere affects the quality perceptions of consumers in Turkey as a developing economy.

Moreover, many previous studies exhibited the effect of price on consumers' quality perception (Agarwal and Teas, 2001; Beneke et al., 2015; Sweeney et al., 1999), risk perception (GonzalezBenito and Martos-Partal, 2012) and attitudes towards private label products (Ahmad et al., 2014; Thanasuta, 2015; Zielke and Komor, 2015) in different countries. The present study proved that a similar situation is valid in Turkey and confirmed the findings of previous studies.

In the current study, it was also found that consumers' perceptions of quality affect their attitudes towards private brands. The finding is similar to the findings of the studies conducted in developing economies such as Malaysia, China and India (Ahmad et al., 2014), as well as developed economies such as Spain (Calvo-Porral and Lang, 2015) and Germany (Olbrich et al., 2017) and confirms these findings. In the study, though not as strong as the perceived quality, it was also found that the perceived risk negatively affects the consumers' attitudes towards private label products. This finding supports the findings of some previous studies (Gomez and Rubio, 2010; Rzem and Debabi, 2012; Sheau-Fen et al., 2012). 
Perhaps the most interesting finding of the current study is that the consumers' perceived quality towards the products of discount stores does not affect their risk perception. Because, regardless of the level of development, the findings of many previous studies (Benek et al., 2015; Kim and Lennon, 2013; Snoj et al., 2004) revealed that the quality perceptions of consumers have a significant effect on their risk perception. However, the findings of our study, including discount stores in Turkey revealed the opposite findings to previous studies.

The most important contribution of this study to the literature is that it reveals a model for consumer attitudes towards private labeled products of discount stores. The SEM fit indices results of the model, presented for the first time in the literature, showed that the model is a suitable and useful model.

In line with the findings, the study also offers important implications to managers. Our findings revealed the effect of the store atmosphere on the perception of quality. In this sense, the right strategies that managers should apply while designing their stores will make the quality perceptions of the consumers towards the products of these stores positive.

On the other hand, the study's findings showed that price affects both perceived quality, perceived risk and attitudes towards private label products. Considering that discount stores operate with EDLP, there are at least two alternatives for managers. First, discount store managers can practice an optimal pricing strategy that, on the one hand, will not reduce the perception of quality, but on the other hand, decrease the risk perception. However, this alternative means driving prices up and operating with high prices, which contrasts with the philosophy of discount merchandising. The second alternative is to persuade the consumer that the difference between discount stores and other stores' prices is not due to quality but to cost, as stated by Quelch and Harding (1996). The author of the study suggests to the managers that the second alternative is pragmatic.

\section{Limitations and Future Researches}

As in every study, there are some limitations in this study. First of all, in the theoretical model of the study, consumer attitudes towards private label products were tried to be explained with four variables. Yet, it is highly likely that there are other variables that affect the consumers' attitudes towards private labels. Moreover, although the stores with the largest number of stores in Turkey are included in the study, there are other stores that offer private label products to consumers.

In this context, in future studies, researchers can expand the model by adding new variables to the model and use the model for other stores that are not included in this study. Moreover, this study was carried out in Turkey as a developing economy. Researchers can compare the results with the results of this study by testing the model in developed or underdeveloped economies. In this direction, it is hoped that the present study will be a guide for future studies.

\section{Financial Support}

The data of this study were collected with the financial support of Scientific Research Projects Coordinatorship of Pamukkale University. 


\section{References}

Aaker, D. A. (1991). Managing Brand Equity: Capitalizing on the Value of a Brand Name, Free Press, New York.

Agarwal, S., \& Teas, R. K. (2002). "Cross-national applicability of a perceived quality model”, Journal of Product \& Brand Management, 11(4), 213-236.

Ahmad, A., Noor, S. M., \& Wel, C. A. C. (2014). "Factors influencing consumers' purchase decision of private label brand products", International Journal of Economic Practices and Theories, 4(2), 101-110.

Ahtola, O. T. (1984). "Price as a 'give' component in an exchange theoretic multicomponent model", Advances in Consumer Research, 11(1), 623-636.

Babin, B. J., Chebat, J. C., \& Michon, R. (2004). "Perceived appropriateness and its effect on quality, affect and behavior", Journal of Retailing and Consumer Services, 11(5), 287-298.

Bagozzi, R. P., Yi, Y. (2012) 'Specification, evaluation, and interpretation of structural equation models', Journal of the Academy of Marketing Science, 40(1), 8-34.

Baker, J., Parasuraman, A., Grewal, D., \& Voss, G. B. (2002). “The influence of multiple store environment cues on perceived merchandise value and patronage intentions", Journal of Marketing, 66(2), 120-141.

Baran, T. (2019). İndirim mağazalarından alışveriş yapanların özel markaya karşı tutumunda algılanan risk ve kalitenin rolü. Pamukkale University, Social Sciences Institute, Unpublished Doctoral Dissertation.

Baran, T. (2020). Marka Adının Tüketicilerin Marka Tercihine Etkisi: Türkçe ve İngilizce Adların Karşılaştırılması. Uluslararası Yönetim İktisat ve İşletme Dergisi, 16(4), 1029-1042.

Baran, T. (2021a), "COVID effect on retailing: a study on consumers' retailer preferences during economic recession periods: evidence from Turkey as a predominantly Muslim society", Journal of Islamic Marketing, Vol. ahead-of-print, No. ahead-of-print. https://doi.org/10.1108/JIMA-09-2020-0292.

Baran, T. (2021b). Tüketicilerin İndirim Mağazalarına Karşı Tutumlarına Yönelik Bir Yapısal Model Önerisi. İşletme Araştırmaları Dergisi. 13(2),1632-1646.

Bardakcı, A. ve Baran, T. (2019). İndirim Mağazalarinin Maliyet Düşürme Stratejileri ve Türkiye’deki Perakendecilerin Verimliliklerinin Karşılaştırılması. Pazarlama Teorisi ve Uygulamaları Dergisi, 5(1), 37-67.

Batra, R., \& Sinha, I. (2000). “Consumer-level factors moderating the success of private label brands”, Journal of Retailing, 76(2), 175-191.

Bauer, R., (1960). Consumer behavior as risk taking. In: Cox, D. (Ed.), Risk Taking and Information Handling in Consumer Behavior. Harvard University Press, Cambridge, 389-398.

Beneke, J. (2012). An application of sweeney's risk-price-quality-value framework through a consideration of store brand merchandise. Journal of Business and Retail Management Research, 7(1), 106-117.

Beneke, J., \& Zimmerman, N. (2014). "Beyond private label panache: The effect of store image and perceived price on brand prestige", Journal of Consumer Marketing, 31(4), 301-311.

Beneke, J., Brito, A., \& Garvey, K. A. (2015). "Propensity to buy private label merchandise: the contributory effects of store image, price, risk, quality and value in the cognitive stream", International Journal of Retail \& Distribution Management, 43(1), 43-62.

Beneke, J., Flynn, R., Greig, T., \& Mukaiwa, M. (2013). “The influence of perceived product quality, relative price and risk on customer value and willingness to buy: a study of private label merchandise", Journal of Product \& Brand Management, 22(3), 218-228.

Berman, B., Evans, J.R., Chatterjee, P. (2018). Retail Management A Strategic Approach, 13th edition, Pearson Education, New Jersey.

Bettman, J. R. (1973). "Perceived risk and its components: a model and empirical test", Journal of Marketing Research, 10(2), 184-190. 
Burton, S., Lichtenstein, D. R., Netemeyer, R. G., \& Garretson, J. A. (1998). "A scale for measuring attitude toward private label products and an examination of its psychological and behavioral correlates", Journal of the Academy of Marketing Science, 26(4), 293.

Calvo Porral, C., \& Lang, M. F. (2015). "Private labels: The role of manufacturer identification, brand loyalty and image on purchase intention", British Food Journal, 117(2), 506-522.

Caplliure, E. M., Curras-Pérez, R., Miquel, M. J., \& Perez-Cabañero, C. (2015). "Attitude, quality and satisfaction toward distributor brands in durable goods: the influence of consumers' price consciousness", In Advances in National Brand and Private Label Marketing (pp. 177-183).

Cheung, G. W., \& Rensvold, R. B. (2002). "Evaluating goodness-of-fit indexes for testing measurement invariance", Structural Equation Modeling, 9(2), 233-255.

Cox, D. F., \& Rich, S. U. (1964). "Perceived risk and consumer decision-making: The case of telephone shopping”, Journal of Marketing Research, 1(4), 32-39.

Dawar, N., \& Parker, P. (1994). "Marketing universals: Consumers' use of brand name, price, physical appearance, and retailer reputation as signals of product quality", Journal of Marketing, 58(2), 81-95.

Dursun, İ., Kabadayı, E. T., Alan, A. K., \& Sezen, B. (2011). "Store brand purchase intention: effects of risk, quality, familiarity and store brand shelf space", Procedia Social and Behavioral Sciences, 24, 1190-1200.

Erdil, T. S. (2015). "Effects of customer brand perceptions on store image and purchase intention: An application in apparel clothing", Procedia-Social and Behavioral Sciences, 207, 196-205.

Fassnacht, M.,\& El Husseini, S. (2013). "EDLP versus Hi-Lo pricing strategies in retailing-a state of the art article”, Journal of Business Economics, 83(3), 259-289.

Gómez, M., \& Rubio, N. (2010). "Re-thinking the relationship between store brand attitude and store brand loyalty: a simultaneous approach", International Review of Retail, Distribution and Consumer Research, 20(5), 515-534.

González-Benito, Ó., \& Martos-Partal, M. (2012). "Role of retailer positioning and product category on the relationship between store brand consumption and store loyalty", Journal of Retailing, 88(2), 236-249.

Grewal, D., Gotlieb, J., \& Marmorstein, H. (1994). The moderating effects of message framing and source credibility on the price-perceived risk relationship. Journal of consumer research, 21(1), 145-153.

Grewal, D., Krishnan, R., Baker, J., \& Borin, N. (1998). “The effect of store name, brand name and price discounts on consumers' evaluations and purchase intentions”, Journal of Retailing, 74(3), 331-352.

https://marketing-dictionary.org/ accessed 20.05.2021

https://www.nielsen.com/wp-content/uploads/sites/3/2019/04/global-private-label-report.pdf $\quad$ accessed 24.05.2021.

Hooper, D., Coughlan, J., \& Mullen, M. (2008). "Structural Equation Modelling: Guidelines for Determining Model Fit", The Electronic Journal of Business Research Methods 6(1), 53-60.

Kim, J., \& Lennon, S. J. (2013). "Effects of reputation and website quality on online consumers' emotion, perceived risk and purchase intention: Based on the stimulus-organism-response model", Journal of Research in Interactive Marketing, 7(1), 33-56.

Kline, R. B. (2011). Principles and Practices of Structural Equation Modeling. The Guilford Press, New York.

Konuk, F. A. (2018). "The role of store image, perceived quality, trust and perceived value in predicting consumers' purchase intentions towards organic private label food", Journal of Retailing and Consumer Services, 43, 304-310.

Koo, D. M. (2003). "Inter-relationships among store images, store satisfaction, and store loyalty among Korea discount retail patrons", Asia Pacific Journal of Marketing and Logistics, 15(4), 42-71. 
Kopalle, P., Biswas, D., Chintagunta, P. K., Fan, J., Pauwels, K., Ratchford, B. T., \& Sills, J. A. (2009). "Retailer pricing and competitive effects", Journal of Retailing, 85(1), 56-70.

Kotler, P. (1973). Atmospherics as a marketing tool. Journal of retailing, 49(4), 48-64.

Kunnan, A. J. (1998). "An introduction to structural equation modelling for language assessment research", Language Testing, 15(3), 295-332.

Laroche, M., Yang, Z., McDougall, G. H., \& Bergeron, J. (2005). “Internet versus bricks-and-mortar retailers: An investigation into intangibility and its consequences", Journal of Retailing, 81(4), 251-267.

Lichtenstein, D. R., Ridgway, N. M., \& Netemeyer, R. G. (1993). Price perceptions and consumer shopping behavior: a field study. Journal of marketing research, 30(2), 234-245.

Marriott, H. R., \& Williams, M. D. (2018). Exploring consumers perceived risk and trust for mobile shopping: A theoretical framework and empirical study. Journal of Retailing and Consumer Services, 42, 133-146.

Martos-Partal, M., González-Benito, O., \& Fustinoni-Venturini, M. (2015). Motivational profiling of store brand shoppers: Differences across quality tiers. Marketing Letters, 26(2), 187-200.

Miranda, M. J., Konya, L., \& Havrila, I. (2005). “Shoppers' satisfaction levels are not the only key to store loyalty", Marketing Intelligence \& Planning, 23(2), 220-232.

Nakip, M. (2013). Pazarlamada araştırma teknikleri: Veri toplama araçları metrik ve metrik olmayan analizler çok değişkenli analizler. Seçkin Yayıncılık, Ankara.

Narasimhan, C., \& Wilcox, R. T. (1998). "Private labels and the channel relationship: a cross-category analysis", The Journal of Business, 71(4), 573-600.

Nunnally, J. C., \& Bernstein, I. H. (1978). Psychometric theory. McGraw-Hill, New York.

Olbrich, R., Jansen, H. C., \& Hundt, M. (2017). "Effects of pricing strategies and product quality on private label and national brand performance", Journal of Retailing and Consumer Services, 34, 294-301.

Ophuis, P. A. O., \& Van Trijp, H. C. (1995). "Perceived quality: A market driven and consumer oriented approach", Food Quality and Preference, 6(3), 177-183.

Poncin, I., \& Mimoun, M. S. B. (2014). “The impact of "e-atmospherics” on physical stores”, Journal of Retailing and Consumer Services, 21(5), 851-859.

Quelch, J. A., \& Harding, D. (1996). “Brands versus Private Labels: Fighting to Win”, Harvard Business Review, January-February, 99-109.

Riboldazzi, S., Capriello, A., \& Martin, D. (2021). Private-label consumer studies: A review and future research agenda. International Journal of Consumer Studies. In press.

Rzem, H., \& Debabi, M. (2012). "Store image as a moderator of store brand attitude”, Journal of Business Studies Quarterly, 4(1), 130.

Schermelleh-Engel, K., Moosbrugger, H., \& Müller, H. (2003). "Evaluating the fit of structural equation models: Tests of significance and descriptive goodness-of - fit measures", Methods of Psychological Research Online, 8(2), 23-74.

Schreiber, J. B., Nora, A., Stage, F. K., Barlow, E. A., \& King, J. (2006). "Reporting structural equation modeling and confirmatory factor analysis results: A review”, Journal of Educational Research, 99(6), 323-338.

Schumacker, R., \& Lomax, R. (1996). A Beginner's Guide to Structural Equation Modeling (Mahwah, NJ: IEA).

Semeijn, J., Riel, A. C., \& Ambrosini, A. B. (2004). "Consumer Evaluations of Store Brands: Effects of Store Image and Product Attributes", Retailing and Consumer Services, 11(4), 247-258.

Sheau-Fen, Y., Sun-May, L., \& Yu-Ghee, W. (2012). "Store brand proneness: Effects of perceived risks, quality and familiarity", Australasian Marketing Journal (AMJ), 20(1), 48-58. 
Sirohi, N., McLaughlin, E. W., \& Wittink, D. R. (1998). "A model of consumer perceptions and store loyalty intentions for a supermarket retailer", Journal of Retailing, 74(2), 223-245.

Snoj, B., Pisnik Korda, A., \& Mumel, D. (2004). “The relationships among perceived quality, perceived risk and perceived product value”, Journal of Product \& Brand Management, 13(3), 156-167.

Steiger, J. H. (2007). "Understanding the limitations of global fit assessment in structural equation modeling", Personality and Individual differences, 42(5), 893-898.

Stone, R. N., \& Grønhaug, K. (1993). "Perceived risk: Further considerations for the marketing discipline”, European Journal of Marketing, 27(3), 39-50.

Sümer, N. (2000). "Yapısal eşitlik modelleri: Temel kavramlar ve örnek uygulamalar”, Türk Psikoloji Yazıları, $3(6), 49-74$.

Sweeney, J. C., Soutar, G. N., \& Johnson, L. W. (1999). “The role of perceived risk in the quality-value relationship: a study in a retail environment", Journal of Retailing, 75(1), 77-105.

Tabachnick, B. G., \& Fidell, L. S. (2007). Using multivariate statistics. Allyn \& Bacon/Pearson Education, Boston.

Thanasuta, K. (2015). “Thai consumers' purchase decisions and private label brands”, International Journal of Emerging Markets, 10(1), 102-121.

Truong, Y., Klink, R. R., Simmons, G., Grinstein, A., \& Palmer, M. (2017). “Branding strategies for hightechnology products: The effects of consumer and product innovativeness", Journal of Business Research, 70, 85-91.

Tsiros, M., \& Hardesty, D. M. (2010). "Ending a price promotion: retracting it in one step or phasing it out gradually", Journal of Marketing, 74(1), 49-64.

Vahie, A., \& Paswan, A. (2006). "Private label brand image: its relationship with store image and national brand", International Journal of Retail \& Distribution Management, 34(1), 67-84.

Wu, P. C., Yeh, G. Y. Y., \& Hsiao, C. R. (2011). “The effect of store image and service quality on brand image and purchase intention for private label brands", Australasian Marketing Journal (AMJ), 19(1), 30-39.

Zeithaml, V. A. (1988). "Consumer perceptions of price, quality, and value: a means-end model and synthesis of evidence”, Journal of Marketing, 52(3), 2-22.

Zielke, S. (2006). "Measurement of retailers' price images with a multiple-item scale", International Review of Retail, Distribution and Consumer Research, 16(3), 297-316.

Zielke, S., \& Komor, M. (2015). "Cross-national differences in price-role orientation and their impact on retail markets”, Journal of the Academy of Marketing Science, 43(2), 159-180.

\section{Resume}

Tamer BARAN (PhD Lecturer), holds Ph.D. degree at General Business from Pamukkale University. His research area is marketing, he has many published studies as international/national articles, papers, book chapters etc. on Branding, Consumer Behavior, Marketing Research and Retailing. He has worked in the Department of Travel-Tourism and Entertainment department of Kale VS of Pamukkale University since 2011. 